\title{
Implementing personalizing approach in teaching academic writing
}

\section{Introduction}

It has long been recognized that personalization is an important aspect in learnercentred teaching. Personal information is more meaningful to students as it relates to their immediate environment. Generally, personality factors are more significant for learning strategy preferences than socio-cultural variables or educational background. And the teacher should be flexible in the choice of methodology in order to respond to the needs of the students and foster learner involvement. This report is based on research, the purpose of which was to study students' individual characteristics and preferred learning styles in the process of university Academic Writing Course in order to run it in a more effective way.

Individual students' differences, language aptitude, role of motivation in foreign language acquisition have been in the focus of classroom-based research since 1950s (VanPatten \& Benati. 2010: 42). Much has been written about preferred approaches to learning in different countries. Researchers state that in some cultures students follow 'basic beliefs, values and consequent behaviour', which factors 'disincline' them towards communicative approaches (Sampson 2010: 284). Active involvement of students in teaching-learning in-class process presupposes matching learning styles to teaching styles with a greater part of 'learning' constituent. According to Nunan, attitudes and expectations of the students are factors that influence effectiveness of a language program (Nunan 1989: 177). Richards suggests that several characteristics of the students be analysed in order 
to ensure the learners' increasing interest and involvement in the learning process (Richards 2001: 101). Although Richards writes mainly about learning languages in general, we suppose his findings can be applicable in narrower learning contexts. Investigating such factors as past learning experiences, learners' expectations for the programme, learners' views on teaching, students' learning approaches, as well as expectations for teacher's and learners' roles can provide valuable material for choosing a more effective teaching approach.

Long-lasting tradition of teacher-centered methods in Ukraine, which presuppose that students follow certain directives and are not intended to consciously participate in teaching-learning process, is still popular in tertiary EFL education. Students traditionally 'feel more comfortable' with a 'domineering' teacher, although it effectively discourages them from critically evaluating any educational information provided. In order to minimize the teacher's domination in the classroom it is essential to learn students' needs focusing on students' learning styles and strategies.

In terms of analysing mental processes which learners employ to use and learn, or procedural knowledge possible correlation have been hypothesized between learning preferences and biographical variables, such as: ethnic group, age group etc. But further research dismantled the hypothesis because within any biographical group the same spectrum of opinion on each learning issue was represented (Nunan 1991: 167-188; Sanotska 2011). This leads to conclusion that personality factors are more significant for learning strategy preferences than socio-cultural variables or educational background. As far as teacher's role is concerned, according to Tudor, the teacher should be flexible in the choice of methodology in order to respond to the needs of the students and foster learner involvement (Tudor 1996:197). Moreover, according to Wenden, students are meant to be self-sufficient problem-solvers, and learner training should be incorporated in the classroom and must be approached systematically (Wenden 1987: 159). Another important aspect in learner-centred teaching is personalizing the teaching-learning process. Personalization, which, according to Taylor means encouraging students to bring their own information into lesson activity, is important in terms of involving students in planning and building their own learning. Taylor asserts that the information which students deliver by themselves is more meaningful to them as it relates to the immediate environment (Taylor 2009: 26).

Although, according to Nunan, 'it is premature to reject the notion that there is no correlation' between learning strategy preferences and the 'good learner', we suppose there is a connection between certain 'good learner' characteristics and the ways learners prefer to work, because successful learners' strategies evidently lead to more effective learning (Nunan 1991: 175). After Rubin and Thompson Nunan states that 'good learners' 'find their own way' in learning the language which implies organizing information about language, finding their own strategies for getting practice in using the language in and out of the classroom, making errors 
work etc. Nunan claims that following the learner-centred approach the teacher can administer surveys and discussions, in which the learners can be encouraged to reflect on their attitudes and preferences (Nunan 1991: 176). Undoubtedly, the advantages of this approach include students' awareness of their own preferred ways of learning, knowing that there are choices in 'what to learn' and 'how to learn'. Moreover, learners become more flexible in their approaches to learning and avoid pitfalls, such as, plagiarizing.

\section{Personalizing and context}

Academic Writing Course is a new course for English Philology students. There were several reasons for its implementation: growing academic mobility, institutional stipulation that all sort of research papers, including diploma and master papers, have to be written and presented in English, as well as general academic requirements to include a summary in English in every research report or paper. The course aims for developing academic writing skills, which involves awareness of academic style, ability to build a paper, ability to write from sources, etc. The course was built based on students' diagnostic testing, which allowed evaluating their proficiency at the beginning of the course. However, the designers understood that only personalized approach would assure the success of the outcome. Thus, in order to build the syllabus the survey alongside with a set of interviews had been administered. Those and ongoing observation made it possible to discover students' preferences and priorities, and even more importantly, identify their learning styles, motivations and expectations.

At the beginning of the course the students expected to learn how to structure academic paper, how to manage time, plan and edit their work and how to write from sources. We investigated the factors which the students find most valuable in their learning process. A survey was carried out in the group of BA English Philology students. The questionnaire included questions about the most and least helpful factors in acquiring writing skills (Table 1).

Table 1. Factors which the students find most helpful in acquiring writing skills

\begin{tabular}{|l|c|c|c|c|}
\hline \multirow{2}{*}{\multicolumn{1}{|c|}{ Activities or factors }} & \multicolumn{4}{c|}{ Rating } \\
\cline { 2 - 5 } & $\mathbf{1 - 3}$ & $\mathbf{4 - 6}$ & $\mathbf{7 - 1 0}$ & Not sure \\
\hline Awareness of grammar rules & $52 \%$ & $34 \%$ & $10 \%$ & $4 \%$ \\
\hline Frequent grammar practice & $0 \%$ & $12 \%$ & $83 \%$ & $5 \%$ \\
\hline Access to literature & $18 \%$ & $60 \%$ & $20 \%$ & $2 \%$ \\
\hline $\begin{array}{l}\text { In-class writing activities with } \\
\text { a teacher }\end{array}$ & $60 \%$ & $12 \%$ & $20 \%$ & $8 \%$ \\
\hline Autonomous writing at home & $0 \%$ & $16 \%$ & $78 \%$ & $6 \%$ \\
\hline Motivation & $0 \%$ & $53 \%$ & $40 \%$ & $7 \%$ \\
\hline
\end{tabular}


Table 1 shows that the students evaluated grammar training higher than rules. The learners also found important two factors: accessing literature and motivation. But motivation proved to be more helpful (40\% of respondents gave it the highest rating: 7-10). Autonomous work at home is more preferable for the vast majority of the respondents (78\%) than in-class activities with a teacher, which was rated 1-3 by more than a half of the learners.

Among the least helpful things the students identified 'poor teaching' (80\%), which means that the authority of the teacher is important, and they expect clearer instructions or more effective training. $60 \%$ of the students mentioned 'fear of making mistakes' and 'being criticized/penalized, which is symptomatic for authoritarian teaching styles and may lead to overall language anxiety. Eventually, poor teaching, in the process of which the teacher dominates, tactlessly criticizes or even humiliates the student, leads to fear of making mistakes and, consequently, makes students disillusioned in this style of classroom teaching and encourage them to seek alternative ways of acquiring knowledge. Unfortunately, in this teaching environment learners who are not motivated do not seem to achieve much progress. Frequent use of L1 as the language of instruction in the English lesson was also regarded as discouraging and least helpful factor.

\section{Personalizing and modes of teaching}

As much as students are traditionally critical of the standards of instruction they receive, it has been generally accepted that the teacher should stimulate their students, for example, by introducing variety in the lesson. Wallace (1991) states that introduction of varied learning modes is possible only if the teacher is clearly aware of the students' learning styles. Hudson (1968) and Parlett (1970) define several types of students according to needs to study or their personal involvement in organizing their studies (cited in Wallace 1991: 20). They divide students into syllabus-bound /syllabus-free, cue-seekers, cue-conscious and cue-deaf learners. Wallace also provides criteria for categorizing learners as active and passive according to their deep or surface approaches to processing a reading text (Wallace 1991: 21). Inevitably, focusing on individual learning styles and preferences will increase productivity of instruction.

The study included an open-ended questionnaire, interviews and observations during the course. The questionnaire provided data about the preferable students' ways of acquiring skills and learning to use systems of the TL. The results are presented in Table 2 . 
Table 2. Students' Styles of Learning English

\begin{tabular}{|c|c|c|c|c|}
\hline \multirow{2}{*}{$\begin{array}{l}\text { Skills and } \\
\text { systems } \\
\text { learning }\end{array}$} & \multicolumn{4}{|c|}{ Best way of } \\
\hline & $\begin{array}{l}\text { on } \\
\text { their } \\
\text { own }\end{array}$ & $\begin{array}{c}\text { with } \\
\text { a teacher }\end{array}$ & specifics & $\begin{array}{l}\text { not } \\
\text { sure }\end{array}$ \\
\hline Vocabulary & $69 \%$ & $8 \%$ & $\begin{array}{c}30 \% \text { - on my own-use dictionary } \\
\text { to fulfill the task }\end{array}$ & $3 \%$ \\
\hline Pronunciation & $42 \%$ & $54 \%$ & $20 \%$ - on my own by reading aloud & $4 \%$ \\
\hline Reading & $50 \%$ & $46 \%$ & 10 - on my own preparing for exams & $4 \%$ \\
\hline Writing & $62 \%$ & $36 \%$ & $\begin{array}{l}60 \text { - on my own by reading } \\
10-\text { on my own by listening }\end{array}$ & $2 \%$ \\
\hline Listening & $72 \%$ & $26 \%$ & 50 - on my own talking to people & $2 \%$ \\
\hline Speaking & $20 \%$ & $76 \%$ & $\begin{array}{c}100 \text { - talking to people in formal } \\
\text { (classroom) and /or informal } \\
\text { situations }\end{array}$ & $4 \%$ \\
\hline
\end{tabular}

Analysis of the data allowed identifying two groups of learners: teacheroriented and independent. Teacher-oriented students expect the teacher to 'help with' their vocabulary or correct misused patterns; to provide the perfect model, which they will follow. The teacher-oriented feel embarrassed if they make mistakes. On the contrary, independent learners appreciate informal situations, in which, they improve their speaking skills interacting with others. The 'independents' do not recognize the authority of the teacher as somebody who is always right because they believe that in many learning situations the role of teacher is optional. They acquire patterns from reading or listening texts and use them in their own writing. They understand that mistakes are a normal learning phenomenon and they can learn more 'not by desperately trying to avoid them but by actually making them'. Strongly motivated independent learners tend to acquire writing skills autonomously, with very little help of the teacher. They learn lexis by constantly using the dictionary, enthusiastically memorizing 'interesting and important words'. In the informal interviews some independent learners complained that "it's too noisy in the classroom, I can't keep words in mind"; 'if I learn words on my own I can focus on the usage, spelling and pronunciation, and if I do it at home, I will remember better".

Besides those two major categories of students, the survey data also allowed to distinguish several kinesthetic learners, who prefer to learn words or acquire writing skills by fulfilling tasks; visual learners, who memorize spelling of words or writing patterns by reading, and auditory students, who claim that they can 'learn faster by listening'. 


\section{Personalizing and collaborative techniques}

Collaborative learning has long been very popular in international foreign language classroom and a central attribute of TEFL. However, this teaching and learning style, which makes use of learners working together in small groups, is hardly a feature of more traditional educational environments. This includes tertiary education in Ukraine, the teacher-centered predominant characteristic of which has been previously discussed. Since the last decades of the last century until now the majority of the internationally published EAP textbooks have been designed for teachers to follow approaches which imply students' autonomy and cooperation in and out of the classroom. Western scholars give evidence of benefits of collaboration/cooperation in foreign language acquisition (Stanfield and Hansen 1983), positive effect of shifting the focus of the 'classroom' from the teacher to students by developing learner autonomy strategies in secondary and higher education. According to Larsen-Freeman and Cameron (2008) teachers do not control their students' learning, 'learners make their own paths', which does not mean that teaching does not influence learning, "teaching and teacher-learner interaction construct and constrain the learning affordances of the classroom. What a teacher can do is manage and serve the students' learning in a way that is consonant with their learning processes" (Larsen-Freeman and Cameron: 199). That is why one of the research questions in this study was whether collaborative techniques are applicable for the students in the academic writing lesson.

As learners share knowledge bringing their previous experiences to the group and learning from the group existing practices, it seems obvious that such style of instruction encourages students' creativity, motivation, enhances their language and study skills, at the same time developing their collaborative skills. Since Academic Writing textbooks involve collaborative activities, the undeniable values of which have been previously discussed, we used personalizing approach to analyse the effectiveness of applying of collaborative techniques in Academic Writing classroom in our context from the perspective of the learner. Customarily, the stages of generating ideas for compositions, brainstorming vocabulary on the topic of the composition, as well as, occasionally, planning writing texts were conducted in the mode of student-to-student interaction or in groups of 3-4. As a rule, the students participated in peer error correction and peer editing, collaborative in-class composition writing. Closely observing the students' inclass work we felt that generally learners feel comfortable when the teacher set tasks involving cooperation in pairs or groups. The statistic data also echo what observation has shown. Table 3 demonstrates that such aspects of academic writing as paraphrasing, summarizing, error correction, editing and proofreading were chosen for collaborative work by the vast majority of students. However, more than a half of respondents would rather generate ideas, build a paragraph, plan and write the essay individually. In other words, according to the statistics, 
the students benefit from cooperation while developing writing skills, but enjoy applying them on their own.

Table 3. Students' preferred modes of interaction in the AW lesson

\begin{tabular}{|l|c|c|c|c|}
\hline \multirow{2}{*}{ Stages of the AW lesson } & \multicolumn{4}{|c|}{ Modes of interaction } \\
\cline { 2 - 5 } & $\mathbf{C p}$ & $\mathbf{C l g}$ & $\mathbf{I}$ & $\mathbf{E}$ \\
\hline Generating ideas & $26 \%$ & $20 \%$ & $54 \%$ & $8 \%$ \\
\hline Building a paragraph & $12 \%$ & $12 \%$ & $68 \%$ & $8 \%$ \\
\hline Planning the essay & $21 \%$ & $18 \%$ & $57 \%$ & $4 \%$ \\
\hline Paraphrasing & $30 \%$ & $38 \%$ & $26 \%$ & $6 \%$ \\
\hline Summarizing & $49 \%$ & $30 \%$ & $13 \%$ & $8 \%$ \\
\hline Error correction & $75 \%$ & $10 \%$ & $13 \%$ & $2 \%$ \\
\hline Editing and proofreading & $55 \%$ & $10 \%$ & $27 \%$ & $8 \%$ \\
\hline Writing a text & $12 \%$ & $12 \%$ & $74 \%$ & $2 \%$ \\
\hline
\end{tabular}

AW—academic writing; $\mathrm{Cp}$ —collaboratively, in pairs; $\mathrm{Clg}$ —collaboratively, in larger groups; $\mathrm{L}$-individually; $\mathrm{E}$ —either

If we compare the percentage of preferred 'pair' or 'group' type of in-class collaboration, we can notice occasionally prevailing tendency to cooperate in pairs (except for paraphrasing activities), especially, at the stage of error correction or editing and proofreading (75\% - Cp versus $10 \% \mathrm{Clg}$ and $55 \% \mathrm{Cp}$ versus $10 \% \mathrm{Clg}$ respectively).

In the interviews absolute majority of the respondents admitted that they enjoy collaborative activities on the whole. They feel more confident negotiating with their fellow-students than reporting directly to the teacher, and, even though they sometimes do not actively participate in discussions, they benefit from listening to others. About half of the group claimed that collaboration with their group-mates in the lesson is 'also helpful' in preparation for exam papers because 'immediate explanation of vague issues is provided on the spot by a peer or the teacher, who monitors group work', and 'energy and optimist' in group discussions is highly motivating. Over $80 \%$ of the learners feel that negotiating with each other develops their self-esteem and self-confidence. About the third of the respondents also stated that cooperating in groups in the lesson helps overcome shyness and improve analytical, speaking and listening skills. However, about a quarter of the students were strongly against collaboration or group discussions in the academic writing lesson for several reasons: 
- they do not feel 'completely comfortable';

- they 'don't want to sound stupid (when they) make mistakes, or feel embarrassed (when those are) corrected';

- they consider writing an essay collaboratively a 'crazy idea';

- they feel biased when stronger students dominate in groups;

- they work at their our own pace, and weaker students can't keep up with the stronger;

- they claim that 'discussions in a writing lesson is s a waste of time, which can be more successfully spent writing'.

\section{Conclusion}

The study reveals that personalizing approach proves to be an effective tool in teaching academic writing. From the results of the study we may draw the following general conclusions. Firstly, personalizing approach to analysing students' preferences, priorities and learning styles allows modifying the Academic Writing Course in order to satisfy the needs of various students and increase its effectiveness. Secondly, in the process of running the course the teacher should use various activities, as well as apply various strategies suitable for different categories of learners. And thirdly, while managing the classroom and administering certain modes of classroom interaction the teacher has to take into account students' preferences.

As a result of implementing research data in classroom work the teacher should demonstrate flexibility by modifying his/her teaching methods and behaviour. This means that the teacher should:

- provide assistance whenever needed, not interfere when the students prefer to work independently;

- apply collaborative techniques with caution, in other words, employ a 'free will' approach allowing students to work either in groups or individually;

- while grouping students, allow them to form their own groups or pairs;

- suggest collaboration as an alternative way of writing out-of-class compositions (group essays), which will allow students to experience cooperation as a beneficial approach and 'alleviate the pressure' of in-class collaborative activities;

- combine the input with students' own discoveries, which will satisfy both groups: teacher-oriented and independent learners.

Consequently, the students will experience the advantages of the teacher's flexible methods because those will allow them to grow into self-sufficient problem-solvers. And obviously, providing they participate in collaborative activities willingly, students will benefit from indisputable positive factors of cooperation. Moreover, learners will systematically develop as learners by: 
- building their own learning strategies, which will evidently lead to more effective learning;

- substituting more effective learning styles for the ones they were used to. Teacher's awareness of students' preferences contributes to increasing students' responsibility for their own learning, which, on the one hand, helps building higher standards of professional competence, and on the other, prepares learners for survival in various academic and social environments. Successful learning strategies will eventually eliminate learning pitfalls and a constructive dialogue between the teacher and the learner will be established.

\section{References}

Larsen-Freeman, D. Cameron, L. 2008. Complex Systems and Applied Linguistics. Oxford: Oxford University Press.

Nunan, D. 1989. Hidden Agendas: the role of the learner in programme implementation. In: R.K. Johnson (Ed.) The Second Language Curriculum. New York: Cambridge University Press, pp. 176-187.

Nunan, D. 1991. Language Teaching Methodology. New York: Prentice Hall.

Richards, J. 2001. Curriculum development in language teaching. Cambridge University Press.

Sampson, R.J. 2010. Student-negotiated Lesson Style. RELC Journal, 41(3), 283-299.

Sanotska, L. 2011. Personalizing learning English with poetry in a cross-cultural education perspective. Paper read at 45 th Annual International IATEFL Conference, Brighton, UK.

Stanfield, C., Hansen J. 1983. Field dependence independence as a variable in second language cloze test performance. TESOL Quarterly 17, 29-38.

Taylor, J. 2009. The Minimax Teacher: Minimise Teacher Input and Maximise Student Output Professional Perspectives. London: Delta ELT Publishing LTD.

Tudor, I. 1996. Learner-centredness as Language Education. Cambridge: Cambridge University Press.

VanPatten, B. Benati A.G. 2010. Key Terms in Second Language Acquisition. Continuum.

Wallace, M.J. 1991. Training Foreign Language Teachers. Cambridge University Press.

Wenden A., Rubin J. 1987. Learner Strategies in Language Learning. New York: Prentice Hall. 